\title{
Effects of Meat Shape and Size, Freezing Method and Thawing Temperature on the Drip Loss of Beef Brisket and the Protein Content of Its Thaw Exudates
}

\author{
Lemuel M. Diamante" and Ngoc Thao My Tran
}

Department of Wine, Food and Molecular Biosciences, Lincoln University, Lincoln 7647, Christchurch, New Zealand

\section{Correspondence to:}

Lemuel M. Diamante, $\mathrm{PhD}$

Department of Wine, Food and Molecular

Biosciences, Lincoln University, Lincoln 7647

Christchurch, New Zealand

Tel: 643211793772

E-mail:1mdiamante2002@yahoo.com

Received: November 24, 2015

Accepted: February 04, 2016

Published: February 06, 2016

Citation: Diamante LM, Tran NTM. 2016. Effects of Meat Shape and Size, Freezing Method and Thawing Temperature on the Drip Loss of Beef Brisket and the Protein Content of Its Thaw Exudates. J Food Chem Nanotechnol 2(1): 14-20.

Copyright: (C) 2016 Diamante and Tran. This is an Open Access article distributed under the terms of the Creative Commons Attribution 4.0 International License (CC-BY) (http:// creativecommons.org/licenses/by/4.0/) which permits commercial use, including reproduction, adaptation, and distribution of the article provided the original author and source are credited..

Published by United Scientific Group

\begin{abstract}
The effects of meat shape and size, freezing method and thawing temperature on the drip loss of beef brisket and the protein content of its thaw exudates were examined in this study. The beef brisket was cut into the following shapes: cube; brick-shape with rectangle cross-section; and brick-shape with square cross-section and were then frozen using a standard freezer $\left(-15^{\circ} \mathrm{C}\right)$, an air-blast freezer $\left(-36^{\circ} \mathrm{C}\right)$ and a deep freezer $\left(-78^{\circ} \mathrm{C}\right)$. After 24 hours, the frozen samples were taken out of the freezer and thawed in an incubator at $25^{\circ} \mathrm{C}$ for 5 hours. In another experiment, the meat was cut into the brick-shape with rectangle cross-section with different sizes and then frozen in another standard freezer and stored until use. The frozen meat samples were thawed in incubators at different air thawing temperatures. The drip loss and protein content in the drip of the samples were determined. There were no significant differences in the drip loss of thawed beef brisket using different freezing methods. For the shapes of beef brisket showed highly significant effect on the drip loss of frozen beef cuts. The drip loss obtained from the sample with brick-shape rectangle cross-section was significantly higher compared to those from samples with cube and brick-shape square cross-section but there was no significant difference in mean values of drip loss between these samples. Furthermore, the drip loss from the sample with smaller size was significantly higher compared to those from samples with bigger sizes. In contrast, there was no significant difference in mean values of drip loss of the samples with bigger sizes. In addition, the drip losses from different thawing temperatures were significantly different. The drip loss of samples thawed at $45^{\circ} \mathrm{C}$ was significantly greater compared to those from samples that were thawed at $25^{\circ} \mathrm{C}$ but not significantly different with the mean values of the samples thawed at $35^{\circ} \mathrm{C}$. The freezing method, shape and size of meat and air thawing temperature had no significant effects on the protein content of exudates from thawed beef briskets, with values ranging from 11 to $12 \%$ wet basis.
\end{abstract}

\section{Keywords}

Meat, Freezing, Thawing, Drip loss, Protein content

\section{Introduction}

Freezing technique, which can decrease product temperatures under the freezing point, has been applied in food for a long time to extend the food shelflife [1] as well as maintain their properties resembling the fresh meat [2]. It is essential to store food when it is harvested excessively or delivered over the far distance for long term consumption [3]. Freezing of foods has been applied widespread because of their considerable advantages, including volatile retention, more limitative modification of sensory, qualities, inhibition of bacterial growth [4]. Therefore, freezing is the main technology in the food industry, especially 
for meat export, the industry that is worth more than US\$13 billion in recent years [1].

There are several freezing methods that have been used for foods. The temperature for standard freezing is $-18^{\circ} \mathrm{C}[5]$. However, there are some problems arising from conventional freezing that endanger the quality of frozen foods, particularly the large size formations of ice crystals $[1,2,6]$. This lead to a serious reduction of quality parameters such as protein content, lipid oxidation, moisture, texture, tenderness, flavor, and color [4]. It was demonstrated that the shape and size of ice crystals depends on freezing rate; therefore, in order to form the extra- and intra-cellular ice nuclei rapidly to prevent the cell damage, the fast freezing rate technologies have been developing such as ultra-low temperature freezing [2]. In addition, there are other freezing methods available for foodstuffs, including: air-blast freezers, fluidized bed freezers, impingement freezers, liquid immersion freezer, plate freezers, and individual quick freezers using liquid $\mathrm{CO}_{2}$ or $\mathrm{N}_{2}$. Among them, air-blast freezing is considered as a common freezing technique because of its versatility. It is a forced convection phenomenon where using the fans to increase the heat transfer coefficient of products surface and induce a more uniform air temperature throughout the freezer. Normally, its evaporator temperature range is from $-35^{\circ} \mathrm{C}$ to $-52{ }^{\circ} \mathrm{C}[7]$.

It is known that the exudates, including thaw loss and/or drip loss, are influenced by freezing methods [1]. According to Leygonie et al. [1], Yu et al. [6] and Añón and Calvelo [8], freezing and thawing modify not only the content but also the distribution of moisture in tissue which is normally used to evaluate the quality characteristic of frozen meat. Ngapo et al. [9] said that when the freezing rate was increased, it might lead to the decrease in drip loss of frozen meat. Therefore, a lot of studies have tried to elucidate the impacts of the freezing process on drip loss; however, the results were not similar [9]. For example, frozen beef cuts in an air-blast at $-30{ }^{\circ} \mathrm{C}$ gave lower drip losses and nitrogenous components in drip than frozen samples in cardboard boxes in still air at $-18^{\circ} \mathrm{C}$ [10]. Sacks et al. [11] also illustrated that freezing methods, including cryogenic at $-65^{\circ} \mathrm{C}$, cryogenic at $-90{ }^{\circ} \mathrm{C}$, walk-infreezer at $-21^{\circ} \mathrm{C}$, blast freezer at $-21{ }^{\circ} \mathrm{C}$, and domestic freezer at $-25{ }^{\circ} \mathrm{C}$, had significant influences on drip loss as well as protein losses of sheep's muscle. Moreover, the effects of combinations of freezing, thawing and frozen storage on drip loss had been examined by Ngapo et al. [9]. They reported that freezing rates interacted with storage time affected the drip loss but there were no differences in the protein concentration and composition of drip or total protein concentration in the drip of pork samples were observed. On the other hand, no significant effects of freezing rates on drip loss were observed from the comparative studies of Bailey [12] which were conducted on rapid freezing at -35 to $-36^{\circ} \mathrm{C}$ and slow freezing at -10 to $-11{ }^{\circ} \mathrm{C}$. Another experiment of Añón and Calvelo [8] showed that neither drip loss nor protein concentration were significantly different between beef samples which had been frozen at different rates. Similarly, Hong et al. [13] reported no significant differences among frozen bighead carp samples in three treatments. These included freezing at $-40{ }^{\circ} \mathrm{C}$ by an ultra-low temperature freezer, frozen at $-40{ }^{\circ} \mathrm{C}$ in the same way for 12 hours and then stored in a freezer at $-18{ }^{\circ} \mathrm{C}$, and frozen at $-18{ }^{\circ} \mathrm{C}$; all of samples were kept for 3 months before analyses.

Various experiments have been carried out for the effect of thawing conditions on the drip loss of frozen meats. Some authors suggested that fast thawing leads to a lower amount of drip loss. As an example, Ngapo et al. [9] reported that drip loss from frozen pork at thawing time of 12 minutes was significantly lower than that from frozen pork at thawing time of 180 minutes. Others demonstrated that fast thawing caused greater amount of drip loss [14] and others showed there was no significant effect [9].

On the other hand, the shape and size factors also affect freezing process. Ilicali et al. [15] suggested that freezing or thawing times of foods depend on the shape and the dimensions of the food which influence the heat transfer coefficient during freezing and thawing periods. Furthermore, it was also said that the wider surface of meat and air contact each other, the more available condition for hemoproteins which are major oxidative catalyst active; causing not only oxidative rancidity but also discoloration [16].

Hence, this study was carried out to examine the effects of meat shape and size, freezing method and thawing temperature on the drip loss of beef brisket and the protein content of its thaw exudates.

\section{Material and Methods}

\section{Raw materials and sample preparation}

The beef brisket was procured from the Independent Meat Processors, Christchurch, New Zealand. The meat was cut into the following shapes: cube $(1.70 \mathrm{~cm} \times 1.70 \mathrm{~cm} \times 1.70 \mathrm{~cm})$; brickshape with rectangle cross-section $(0.50 \mathrm{~cm} \times 1.70 \mathrm{~cm} \times 5.80$ $\mathrm{cm})$; brick-shape with square cross-section $(1.25 \mathrm{~cm} \times 1.25$ $\mathrm{cm} \times 3.15 \mathrm{~cm}$ ). All the meat cuts would be having a volume of about $5 \mathrm{~cm}^{3}$. Twelve pieces of meat cut of different shapes. Three pieces of each meat cut were held in a chiller at $3{ }^{\circ} \mathrm{C}$ and served as the controls. After that, three pieces of each meat cut were frozen using the standard freezer at $-15{ }^{\circ} \mathrm{C}$, three pieces of each meat cut were frozen using the air-blast freezer at $-36^{\circ} \mathrm{C}$ and $1.6 \mathrm{~m} / \mathrm{s}$, and three pieces of each meat cut were frozen using a deep freezer at $-78^{\circ} \mathrm{C}$. After 24 hours, the frozen samples were taken out of the freezer and thawed in an incubator at $25^{\circ} \mathrm{C}$ for 5 hours by placing each meat cut in a centrifuge tube $(50 \mathrm{ml})$ and suspended by using a cloth mesh. The centrifuge tubes were weighed prior to putting in the meat cuts. The drip loss and total protein content in the drip of the samples were determined.

For the experiment on effect of sample size and thawing temperature on the drip loss, the meat was cut into the brickshape with rectangle cross-section with different sizes $(0.50$ $\mathrm{cm} \times 1.70 \mathrm{~cm} \times 5.80 \mathrm{~cm}, 1.00 \mathrm{~cm}$ x $1.70 \mathrm{~cm}$ x $5.80 \mathrm{~cm}, 1.50 \mathrm{~cm}$ $\mathrm{x} 1.70 \mathrm{~cm} \mathrm{x} 5.80 \mathrm{~cm}$ ). Nine pieces of meat cut of different sizes were frozen in another standard freezer at $-22{ }^{\circ} \mathrm{C}$ and stored until use. Three pieces of each meat cut were taken out of the freezer and thawed in an incubator at $25^{\circ} \mathrm{C}, 35^{\circ} \mathrm{C}$, and $45^{\circ} \mathrm{C}$. All the samples were thawed for 3 hours by placing each meat 
cut in a centrifuge tube $(50 \mathrm{ml})$ and suspended by using a cloth mesh. The centrifuge tubes were weighed prior to putting in the meat cuts. The drip loss of the samples was determined after thawing.

\section{Drip loss determination}

The samples were centrifuged at $1000 \mathrm{~g}$ for 10 minutes after thawing. The meat samples were removed from the centrifuge tubes before the amount of drip was obtained by weighing. This centrifuging method to evaluate drip loss on thawing was described by Añón and Calvelo [8]. Drip loss of these samples was determined as:

\section{Drip Loss $=(100 \times$ Drip Weight $) /$ Initial Meat Weight}

The samples thaw exudates were stored in the centrifuge tubes in a chiller until the total protein content was determined using the Kjeldahl method.

\section{Protein determination}

The protein content in the drip of the samples was determined by the Kjeldahl method as described by Wrolstad et al. [17]. This method determines the protein content through the nitrogen content of the sample multiplied by a conversion factor. The sample is digested in sulfuric acid and $\mathrm{N}$ converts to $\mathrm{NH}_{3}$, using $\mathrm{CuSO}_{4} / \mathrm{TiO}_{2}$ as the catalysts. $\mathrm{NH}_{3}$ is distilled and reacts with $\mathrm{H}_{2} \mathrm{SO}_{4}$ standard in a distillation apparatus. The excess standard acid in distillate with $0.1 \mathrm{~N} \mathrm{NaOH}$ standard solution is titrated in order to calculate the nitrogen content as well as the protein content (\% wet basis).

\section{Statistical analysis}

Three independent trials were conducted to examine the effect of meat shape and size, freezing method and thawing temperature on the drip loss of beef brisket and the protein content. All the specific assays were carried in triplicate. The data were analyzed by using the Minitab 16 software. Analysis of variance (ANOVA) was conducted to determine the significance of the main effects. Significant differences $(P<0.05)$ among means were identified using the Tukey test.

\section{Results and Discussions}

\section{Effect of freezing methods on drip loss of thawed beef}

Table 1 shows the mean values of drip loss of thawed beef brisket using different freezing methods. The results show that the mean drip loss of the samples with different shapes regardless of the freezing method used was around 11-12\%. The control samples with different shapes stored in a chiller $\left(3{ }^{\circ} \mathrm{C}\right)$ had mean drip loss which ranged from $5-7 \%$. Statistical analysis for the values of drip loss of thawed beef brisket using different freezing methods and the control samples showed a highly significant difference. This means that the drip loss of the thawed samples using different freezing methods were higher than the control samples.

The results indicate that the different freezing temperature influence to drip loss is not obvious during freezing process. Añón and Calvelo [8] also found no significant differences of drip loss between beef samples which had been frozen at different rates. They said that beside the effect from freezing conditions, the exudates of frozen meats also depended on both post-mortem treatment (loss of ATP, $\mathrm{pH}$ reduction) before they were frozen and the thawing conditions. It was found that other factors, such as $\mathrm{pH}$ had more impact on drip loss than the freezing rate [6]. Furthermore, Bailey [12] also claimed that freezing rate had no significant effect on drip loss when he compared vacuum packaged pork chops after treated by rapid freezing at -35 to $-36{ }^{\circ} \mathrm{C}$ and $4 \mathrm{~m} / \mathrm{s}$ with slow freezing at -10 to $-11^{\circ} \mathrm{C}$ and air velocity practically zero. Moreover, drip loss released from the frozen and thawed meat is affected not only freezing method but also frozen storage temperature [6]. In the study of Ngapo et al. [9], the main influence of freezing rate on drip from small samples of pork was not significant but the combination of six freezing rates, two storage times at $-20{ }^{\circ} \mathrm{C}$ was observed almost significant. According Ngapo et al. [9] and Mortensen et al. [18], during storage period, ice recrystallization appears leading to the development of the ice crystals that was formed during freezing procedure. As result, in the growth of the ice crystals, inducing the risk of tissue damage; consequently, after the storage period, drip loss collected reaching a maximum. In this work, the effect of freezing method on drip loss of beef cuts without storage has been explored; therefore, the effect of different freezing method on the volume of drip has not been observed. Although freezing method has no significant effect on drip loss, it was illustrated that a slight decrease in the mean values of drip loss of frozen beef when decreased freezing temperature. The significant difference in means drip loss between fresh beef samples and frozen beef samples demonstrated there was a significant effect of freezing on drip loss due to ice crystal formation during freezing process causing tissue disruption.

Table 1: Mean values of drip loss of thawed beef brisket with differen sample shapes and a volume of $5 \mathrm{~cm}^{3}$ and using a chiller and different freezing methods and thawed in air at $25^{\circ} \mathrm{C}$ for 5 hours.

\begin{tabular}{|c|c|c|c|c|c|}
\hline Sample & \multicolumn{5}{|c|}{ Drip loss (\%) } \\
\hline \multicolumn{6}{|c|}{ Freezing Methods } \\
\hline & $\begin{array}{l}\text { Chiller } \\
\left(3{ }^{\circ} \mathrm{C}\right)\end{array}$ & $\begin{array}{c}\text { Standard }{ }^{\#} \\
\text { freezing } \\
\left(-15^{\circ} \mathrm{C}\right)\end{array}$ & $\begin{array}{c}\text { Air-blast }{ }^{\sharp} \\
\text { freezing } \\
\left(-36^{\circ} \mathrm{C}\right)\end{array}$ & $\begin{array}{l}\text { Deep" } \\
\text { freezing } \\
\left(-78^{\circ} \mathrm{C}\right)\end{array}$ & 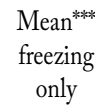 \\
\hline Cube $^{\#}$ & 4.81 & 7.95 & 10.79 & 8.71 & $9.15 \mathrm{a}$ \\
\hline $\mathrm{BSSC}^{\#}$ & 7.44 & 11.06 & 9.91 & 9.38 & $10.12 \mathrm{a}$ \\
\hline $\mathrm{BSRC}^{\#}$ & 4.86 & 16.78 & 9.91 & 13.43 & $14.82 \mathrm{~b}$ \\
\hline Mean & $5.70 \mathrm{a}$ & $11.93 \mathrm{~b}$ & $11.64 \mathrm{~b}$ & $10.51 \mathrm{~b}$ & \\
\hline
\end{tabular}

BSSC - Brick shape (square cross-section); BSRC - Brick shape (rectangle cross section)

\# Mean of 3 measurements **** significant at $0.1 \%$ level

Means with the same letters are not significantly different from each other

\section{Effect of shape on drip loss of thawed beef}

The mean drip loss of thawed beef brisket with different shapes ranged from 9 to $15 \%$ [Table 1]. The meat cuts had 
similar volume of about $5 \mathrm{~cm}^{3}$ but different surface areas. The calculated surface areas of beef cuts from cube, brick-shape with square cross-section, and brick-shape with rectangle cross-section were $17.34 \mathrm{~cm}^{2}, 18.875 \mathrm{~cm}^{2}$, and $27.22 \mathrm{~cm}^{2}$, respectively. Statistical analysis showed that the shape of the samples was highly significantly different from each other. Further analysis using the Tukey test showed that the drip loss from the sample with brick-shape rectangle cross-section was significantly higher compared to those from samples with cube and brick-shape square cross-section. However, there was no significant difference in mean values of drip loss of the samples with cube and brick-shape square cross-section [Table 1]. The sample with brick-shape rectangle cross-section had higher surface area resulting in greater drip loss compared with the samples with cube and brick-shape square crosssection. Interestingly, the samples with cube and brick-shape square cross-section had closer surface areas which resulted in no significant difference on their drip loss.

The mean drip loss of thawed beef can be related to the shape of the sample (surface area) using the equation,

$$
y=0.570 S A-0.695 \quad R^{2}=1.000
$$

where: $y=\operatorname{drip}$ loss (\%) and $S A=$ sample surface area $\left(\mathrm{cm}^{2}\right)$. The regression equation has a very high $R^{2}(1.000)$ which means that both parameters are very highly correlated.

While the freezing process is often considered the cause of change in the amount of drip loss, the effect of shape factor, have so far been ignored. Ilicali et al. [15] said that freezing and thawing times of frozen food are also influenced by the shape of food. They suggested that freezing rate was not an important factor impact the amount of drip but when it combined with the ratio between volume and area of cut surface of muscle tissue, the significant difference of drip was observed. According them, in the small meat cuts, when surface area was large in comparison with volume of meat, the amount of drip loss depends on freezing temperature. On the other hand, in large beef cuts, the "frozen out" water has been reabsorbed by muscle tissue leading to the low in drip loss whereas the water in small beef cuts was able to more rapidly lose by the tissue damage of ice crystals before it could be reabsorbed.

Effect of thawing temperatures and sample sizes on drip loss of thawed beef

Table 2 shows the mean values of drip loss of frozen beef brisket using different thawing temperatures. The results show that the mean drip loss of the samples with different sizes thawed at $25^{\circ} \mathrm{C}, 35^{\circ} \mathrm{C}$, and $45^{\circ} \mathrm{C}$ were $14.53 \%, 19.13 \%$, $21.48 \%$, respectively. Statistical analysis showed that the drip loss from different thawing temperatures were significantly different from each other. Further analysis using the Tukey test showed that the drip loss from the samples thawed at $25{ }^{\circ} \mathrm{C}$ was significantly lower compared to those from samples were thawed at $45^{\circ} \mathrm{C}$. However, there was no significant difference in mean values of drip loss of the samples were thawed at $35^{\circ} \mathrm{C}$ compared with those of others [Table 2].

In this study, the effect of thawing temperature on drip loss of frozen beef brisket has been explored. Drip loss depends on thawing temperature as well as the rate of thawing. Experimental
Table 2: Mean values of drip loss of thawed beef brisket with different sample sizes frozen at $-22^{\circ} \mathrm{C}$ in a standard freezer and using different air thawing temperatures for 3 hours.

\begin{tabular}{|c|c|c|c|c|}
\hline Sample & \multicolumn{4}{|c|}{ Drip loss (\%) } \\
\hline & \multicolumn{4}{|c|}{ Air thawing temperature } \\
\hline & $25^{\circ} \mathrm{C}^{\#}$ & $35^{\circ} \mathrm{C}^{\#}$ & $45^{\circ} \mathrm{C}^{\#}$ & Mean \\
\hline $\mathrm{BS}_{\text {small }}{ }^{*}$ & 17.00 & 26.74 & 27.56 & $23.77 \mathrm{~b}$ \\
\hline BS medium $^{\#}$ & 14.41 & 17.88 & 17.48 & $16.59 \mathrm{a}$ \\
\hline BS large $^{\#}$ & 12.18 & 12.78 & 19.40 & $14.79 \mathrm{a}$ \\
\hline Mean" & $14.53 \mathrm{a}$ & $19.13 \mathrm{ab}$ & $21.48 \mathrm{~b}$ & \\
\hline
\end{tabular}

BS small - brick shape with $0.50 \mathrm{~cm} \times 1.70 \mathrm{~cm} \times 5.80 \mathrm{~cm}$ dimensions; BS medium - brick shape with $1.00 \mathrm{~cm} \times 1.70 \mathrm{~cm} \times 5.80 \mathrm{~cm}$ dimensions; BS large - brick shape with $1.50 \mathrm{~cm} \times 1.70 \mathrm{~cm} \times 5.80 \mathrm{~cm}$ dimensions \# mean of 3 measurements **** significant at $0.1 \%$ level * significant at $5 \%$ level

Means with the same letters are not significantly different from each other.

results indicate that the drip loss from frozen samples increased with increasing thawing temperature. Sayre et al. [19] reported that there were no significant differences in the amount of drip from porcine muscles that were thawed at 1 and $7{ }^{\circ} \mathrm{C}$ whereas a greater amount of drip loss was obtained from the thawed muscles at $20{ }^{\circ} \mathrm{C}$. Yu et al. [20] also showed that the drip losses of frozen chicken breast and leg muscles thawed at $18{ }^{\circ} \mathrm{C}$ were greater than those from the samples were thawed at $2{ }^{\circ} \mathrm{C}$ and $0{ }^{\circ} \mathrm{C}$. The observations are fundamentally in line with the results in the present experiment. At the higher temperature, it means higher thawing rate, Pham [21] suggested that water was given inadequate time in order to be reabsorbed into the cellular structure as a result of fast thawing. Furthermore, it was thought that the water loss came from the volume changes of the myofibrils during thawing. The cross linkage between actin and myosin caused the shrinkage of myofibrils resulted in the higher amount of free water which could be lost from the muscle. Therefore, the higher thawing temperature was, increased muscle shortening, resulting in increased drip loss [20].

The mean drip loss of thawed beef brisket with different sizes ranged from 14 to $24 \%$ [Table 2]. The meat cuts had different thickness which resulted to different surface areas and volumes. The calculated surface-to-volume ratios of beef cuts from the different sample sizes $(0.50 \mathrm{~cm} \times 1.70 \mathrm{~cm} \times 5.80 \mathrm{~cm}, 1.00$ $\mathrm{cm} \times 1.70 \mathrm{~cm} \times 5.80 \mathrm{~cm}, 1.50 \mathrm{~cm} \times 1.70 \mathrm{~cm} \times 5.80 \mathrm{~cm})$ were $5.52,3.52$, and $2.85 \mathrm{~cm}^{2} / \mathrm{cm}^{3}$, respectively. Statistical analysis of the mean drip loss showed that the sample sizes (surfaceto-volume ratios) were significantly different from each other. Further analysis using the Tukey test showed that the drip loss from the sample with smaller size $(0.50 \mathrm{~cm} \times 1.70 \mathrm{~cm} \times 5.80 \mathrm{~cm})$ was significantly higher compared to those from samples with bigger sizes $(1.00 \mathrm{~cm} \times 1.70 \mathrm{~cm} \times 5.80 \mathrm{~cm}, 1.50 \mathrm{~cm} \times 1.70 \mathrm{~cm}$ $\mathrm{x} 5.80 \mathrm{~cm}$ ) due to differences in their surface-to-volume ratios. On the other hand, there was no significant difference in mean values of drip loss for the samples with bigger sizes [Table 2] because of their closer surface-to-volume ratios.

These results are in concurrence with the findings of Khan 
and Lentz [10] who suggested that the volume of drip loss was affected by the thickness and the surface-to-volume ratio of meat cut. This was illustrated in their experiment when the thickness of beef samples was increased; there was significant decrease in the amount of drip loss. Furthermore, in the similar situation with the shapes of beef cuts that were discussed in the previous section, the higher sample thickness, this means lower surface-to-volume ratio caused more water reabsorption during thawing period; resulted in lower drip loss.

The effects of both the thawing temperature and sample size (surface-to-volume ratio) on the drip loss can be simultaneously modelled by the equation below,

$$
y=-7.316+3.415 S V+0.3475 T T \quad R^{2}=0.851
$$

where: $y=\operatorname{drip}$ loss (\%), $S V=$ surface-to-volume ratio $\left(\mathrm{cm}^{2} / \mathrm{cm}^{3}\right)$ and $T T=$ air thawing temperature $\left({ }^{\circ} \mathrm{C}\right)$. The equation has an $\mathrm{R}^{2}$ of 0.85 which means that drip loss can be related to both factors. Table 3 shows that the calculated mean relative percentage error is $10.08 \%$ when comparing between the experimental and predicted values which is acceptable for most engineering applications [22]. The results show that the equation can represent the effects of both factors on the drip loss of thawed beef.

Table 3: Mean relative percentage error of drip loss of thawed beef brisket using the mathematical model with different sizes and surface-to-volume ratio (SV) frozen at $-22{ }^{\circ} \mathrm{C}$ in a standard freezer and using different air thawing temperatures (TT) for 3 hours.

\begin{tabular}{|l|l|l|cc|c||}
\hline Size & SV $\left(\mathbf{c m}^{2} / \mathbf{c m}^{3}\right)$ & TT $\left({ }^{\circ} \mathbf{C}\right)$ & \multicolumn{2}{|c|}{ \% Drip loss } & Percent error \\
& & & Experimental & Predicted & \\
\hline Small & 5.52 & 25 & 17.00 & 20.22 & 18.94 \\
& & 35 & 26.74 & 23.70 & 11.37 \\
& & 45 & 27.56 & 27.17 & 1.44 \\
\hline Medium & 3.52 & 25 & 14.41 & 13.39 & 7.08 \\
& & 35 & 17.88 & 16.87 & 5.65 \\
& & 45 & 17.48 & 20.34 & 16.36 \\
\hline Large & 2.85 & 25 & 12.18 & 11.10 & 8.87 \\
& & 35 & 12.78 & 14.58 & 14.08 \\
& & 45 & 19.40 & 18.05 & 6.96 \\
\hline \multicolumn{5}{|c}{ Mean relative percentage error } & 10.08 \\
\hline
\end{tabular}

Small size - brick shape with $0.50 \mathrm{~cm}$ x $1.70 \mathrm{~cm}$ x $5.80 \mathrm{~cm}$ dimensions; Medium size - brick shape with $1.00 \mathrm{~cm} \times 1.70 \mathrm{~cm}$ x $5.80 \mathrm{~cm}$ dimensions; Large size - brick shape with $1.50 \mathrm{~cm} \times 1.70 \mathrm{~cm} \times 5.80 \mathrm{~cm}$ dimensions

Figure 1 is surface plot for mean drip loss of thawed beef as affected by thawing temperatures and samples sizes as predicted using the above equation. The results show that the greater the thawing temperature and surface-to-volume ratio, the higher the drip loss of thawed beef.

These results are in agreement with those of Añón and Calvelo [8] for samples of beef. In their experiment, the protein content from the exudates of fresh samples was similar to those from the exudates of frozen samples. Similarly, Ngapo et al. [9] reported that there were no significant differences in the protein content of the drip loss of pork

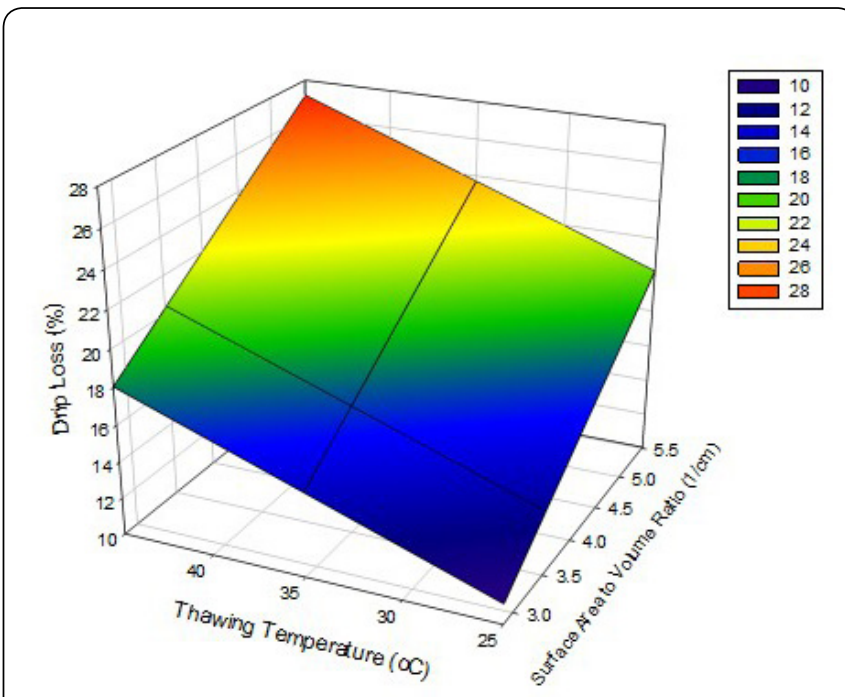

Figure 1: Surface plot for mean drip loss of thawed beef as affected by thawing temperatures and surface-to-volume ratio (sizes) (legend shows the range of values on the response surface.

obtained after different freezing treatment. Both Añón and Calvelo [8] and Ngapo et al. [9] suggested that protein contents were not observed to change by freezing but these were actually reduced during frozen storage period. In the present study, the analysis was carried out from the centrifuged drip and not in whole meat samples which were frozen and thawed without prolong storage time. This may explain for the similar protein content result between frozen beef samples from different freezing methods.

Effect of sample sizes of meat and air thawing temperatures on protein content of exudates

Table 4 shows the mean values of protein content of exudates from thawed beef brisket using different shapes and freezing methods. On the other hand, Table 5 presents the mean values of protein content of exudates from thawed beef brisket with different sizes of meat frozen at $-22{ }^{\circ} \mathrm{C}$ in a standard freezer and using different air thawing temperatures for 3 hours. The results show that the mean protein content of the samples with different shapes using different sizes of meat and air thawing temperature were about 11 to $12 \%$ wet basis which was the same as the control samples with different sample shapes stored in a chiller $\left(3^{\circ} \mathrm{C}\right)$. Statistical analysis for the values of protein content of thawed beef brisket exudates with different shapes and sizes of meat, freezing method and air thawing temperatures, as well as the control samples showed that there were no significant differences between them. This means there were no effects of these factors in the protein content of exudates from thawed beef brisket cuts. The different shapes and sizes of meat, freezing method and air thawing temperatures were expected to give no significant differences on the protein content of thaw exudates as shown in the studies on frozen pork samples [9].

\section{Conclusion}

This study found that there were no significant differences in the drip loss of thawed beef brisket using different freezing methods; however, the drip losses of the thawed samples 
Table 4: Mean values of protein content of exudates from thawed beef brisket with different shape and using different freezing methods and thawed in air at $25^{\circ} \mathrm{C}$ for 5 hours.

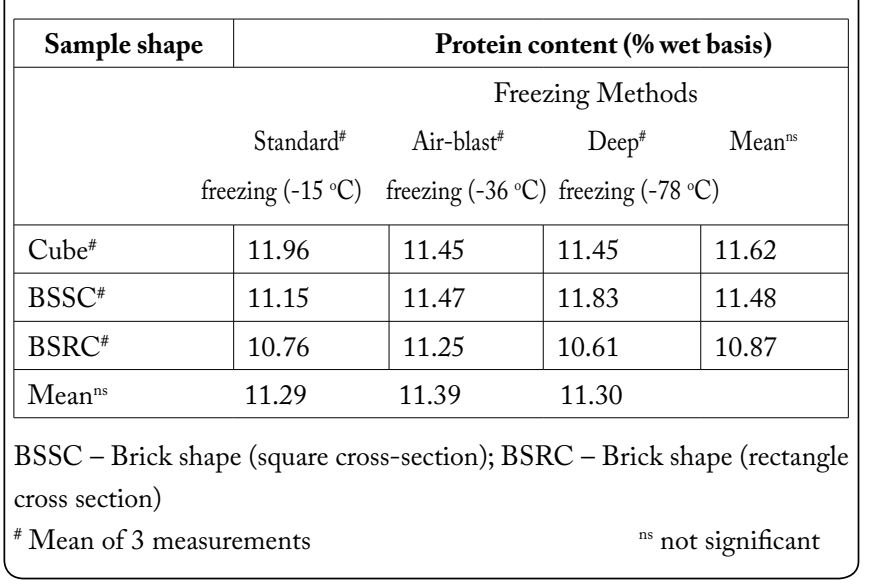

Table 5: Mean values of protein content of exudates from thawed beef brisket with different sample sizes frozen at $-22{ }^{\circ} \mathrm{C}$ in a standard freezer and using different air thawing temperatures for 3 hours.

\begin{tabular}{|c|c|c|c|c|}
\hline \multirow[t]{3}{*}{ Sample shape } & \multicolumn{4}{|c|}{ Protein content (\% wet basis) } \\
\hline & \multirow[b]{2}{*}{$25^{\circ} \mathrm{C}^{\#}$} & \multirow[b]{2}{*}{$35^{\circ} \mathrm{C}^{\#}$} & \multicolumn{2}{|c|}{ Air thawing temperature } \\
\hline & & & $45^{\circ} \mathrm{C}^{\#}$ & Mean $^{\text {ns }}$ \\
\hline BS small\# & 11.25 & 11.37 & 11.41 & 11.34 \\
\hline BS medium\# & 11.70 & 11.55 & 11.04 & 11.43 \\
\hline BS large\# & 10.97 & 11.35 & 11.01 & 11.11 \\
\hline Mean $^{\text {ns }}$ & 11.31 & 11.42 & 11.15 & \\
\hline
\end{tabular}

BS small - brick shape with $0.50 \mathrm{~cm} \times 1.70 \mathrm{~cm}$ x $5.80 \mathrm{~cm}$ dimensions; BS medium - brick shape with $1.00 \mathrm{~cm} \times 1.70 \mathrm{~cm} \times 5.80 \mathrm{~cm}$ dimensions; BS large - brick shape with $1.50 \mathrm{~cm} \times 1.70 \mathrm{~cm}$ x $5.80 \mathrm{~cm}$ dimensions. \# mean of 3 measurements

${ }^{\text {ns }}$ not significant

using different freezing methods were higher than the control samples. For the shapes of beef brisket showed high significant effect on the drip loss of frozen beef cuts; particularly, drip loss obtained from the sample with brick-shape rectangle cross-section was significantly higher compared to those from samples with cube and brick-shape square cross-section but there was no significant difference in mean values of drip loss between these samples. The drip loss from the sample with smaller size $(0.50 \mathrm{~cm} \times 1.70 \mathrm{~cm} \times 5.80 \mathrm{~cm})$ was significantly higher compared to those from samples with bigger sizes due to lower surface-to-volume ratios. In contrast, there was no significant difference in mean values of drip loss of the samples with bigger sizes $(1.00 \mathrm{~cm} \times 1.70 \mathrm{~cm} \times 5.80 \mathrm{~cm}, 1.50 \mathrm{~cm} \times$ $1.70 \mathrm{~cm} \times 5.80 \mathrm{~cm}$ ) because they had closer surface-to-volume ratios. In addition, the drip losses from different thawing temperatures were significantly different. The results indicated that the drip loss of samples thawed at $45^{\circ} \mathrm{C}$ was significantly greater compared to those from samples that were thawed at $25^{\circ} \mathrm{C}$; but there was no significant difference in mean values of drip loss of the samples that were thawed at $35^{\circ} \mathrm{C}$ compared with those of others. On the other hand, freezing method, shape and size of meat and air thawing temperatures had no significant effect on the protein content of exudates from thawed beef brisket cuts with a range of 11 to $12 \%$ wet basis.

\section{References}

1. Leygonie C, Britz TJ, Hoffman LC. 2012. Impact of freezing and thawing on the quality of meat: Review. Meat Sci 91(2): 93-98. doi: 10.1016/j.meatsci.2012.01.013

2. Muela E, Sañudo C, Campo MM, Medel I, Beltrán JA. 2010. Effect of freezing method and frozen storage duration on instrumental quality of lamb throughout display. Meat Sci 84(4): 662-669. doi: 10.1016/j. meatsci.2009.10.028

3. Jeremiah LE. 2004. Refrigeration and freezing technology: Freezing and Food Quality. In: Jensen WK, Devine C, Dikeman M (eds) Encyclopedia of Meat Sciences. Elsevier BV, Netherlands, pp 11561161.

4. Martino MN, Otero L, Sanz PD, Zaritzky NE. 1998. Size and location of ice crystals in pork frozen by high-pressure-assisted freezing as compared to classical methods. Meat Sci 50(3): 303-313. doi: 10.1016/ S0309-1740(98)00038-2

5. Farouk MM, Wieliczko KJ, Merts I. 2004. Ultra-fast freezing and low storage temperatures are not necessary to maintain the functional properties of manufacturing beef. Meat Sci 66(1): 171-179. doi: 10.1016/S0309-1740(03)00081-0

6. Yu XL, Li XB, Zhao L, Xu XL, Ma HJ, et al. 2010. Effects of different freezing rates and thawing rates on the manufacturing properties and structure of pork. J Muscle Foods 21(2): 177-196. doi: 10.1111/j.17454573.2009. 00175.x

7. Dempsey P, Bansal P. 2012. The art of air blast freezing: Design and efficiency considerations. Applied Thermal Engineering 41: 71-83. doi: 10.1016/j.applthermaleng.2011.12.013

8. Añón MC, Calvelo A. 1980. Freezing rate effects on the drip loss of frozen beef. Meat Sci 4(1): 1-14. doi: 10.1016/0309-1740(80)90018-2

9. Ngapo TM, Babare IH, Reynolds J, Mawson RF. 1999. Freezing and thawing rate effects on drip loss from samples of pork. Meat Sci 53(3): 149-158. doi:10.1016/S0309-1740(99)00050-9

10. Khan AW, Lentz CP. 1977. Effects of freezing, thawing and storage on some quality factors for portion-size beef cuts. Meat Sci 1(4): 263-270. doi: 10.1016/0309-1740(77)90021-3

11. Sacks B, Casey NH, Boshof E, van Zyl H. 1993. Influence of freezing method on thaw drip and protein loss of low-voltage electrically stimulated and non-stimulated sheep's' muscle. Meat Sci 34(2): 235-243. doi: 10.1016/0309-1740(93)90030-L

12. Bailey C. 1972. A preliminary experiment on the effect of freezing rate on drip and quality of small cuts of meat. Meat Research Institute Memorandum. Number 19, pp 8.

13. Hong H, Luo Y, Zhou Z, Bao Y, Lu H, et al. 2013. Effects of different freezing treatments on the biogenic amine and quality changes of bighead carp (Aristichthys nobilis) heads during ice storage. Food Chem 138(2-3) 1476-1482. doi: 10.1016/j.foodchem.2012.11.031

14. Ambrosiadis I, Theodorakakos N, Georgakis S, Lekas S. 1994. Influence of thawing methods on the quality of frozen meat and the drip loss. Fleischwirtschaft 74(3): 284-287.

15. Ilicali C, Teik, TH, Shian, LP. 1999. Improved formulations of shape factors for the freezing and thawing time prediction of foods. $L W T$ Food Science and Technology 32(5): 312-315. doi:10.1006/fstl.1999.0533

16. Mai J, Kinsella JE. 1980. Composition of lipids and proteins of deboned minced and filleted white sucker (Catostomus commersoni). J Food Biochem 3(4): 229-239. doi: 10.1111/j.1745-4514. 1980.tb00779.x

17. Wrolstad R, Acree T, Decker E, Penner M, Reid D, et al. 2005. Handbook of food analytical chemistry: Water, proteins, enzymes, lipids, and carbohydrates. John Wiley \& Son, Inc., USA.

18. Mortensen M, Andersen HJ, Engelsen SB, Bertram HC. 2006. Effect of freezing temperature, thawing and cooking rate on water 
distribution in two pork qualities. Meat Sci 72(1): 34-42. doi: 10.1016/j. meatsci.2005.05.027

19. Sayre RN, Kiernat B, Briskey EJ. 1964. Processing characteristics of porcine muscle related to $\mathrm{pH}$ and temperature during rigor mortis development and to gross morphology 24 hrs. post-mortem. J Food Sci 29(2): 175-181. doi: 10.1111/j.1365-2621. 1964.tb01714.x

20. Yu LH, Lee ES, Jeong JY, Park HD, Choi JH, et al. 2005. Effects of thawing temperature on the physicochemical properties of pre-rigor frozen chicken breast and leg muscles. Meat Sci 71(2): 375-382. doi: 10.1016/j.meatsci.2005.04.020

21. Pham QT. 2004. Refrigeration and freezing technology: Thawing. In: Jensen WK, Devine C, Dikeman M (eds) Encyclopedia of Meat Sciences. Elsevier BV, Netherlands, pp 1150-1156.

22. Diamante LM, Ihns R, Savage GP, Vanhanen L. 2010. A new mathematical model for thin layer drying of fruits. Int J Food Sci Tech 45(9): 1956-1962. doi: 10.1111/j.1365-2621.2010.02345.x 